\title{
The Effect of Balance Exercises on Speed and Agility in Physical Education Lessons
}

\author{
Hakan Acar*, Nebahat Eler \\ Department of Physical Education and Sport, Zonguldak Bülent Ecevit University, Turkey
}

Copyright $\mathrm{C} 2019$ by authors, all rights reserved. Authors agree that this article remains permanently open access under the terms of the Creative Commons Attribution License 4.0 International License

\begin{abstract}
The aim of this study is to investigate the effects of 8-week balance exercises on the speed and agility in 10-12 year-old children in physical education lessons. A total of 789 students participated in the study voluntarily. The students were randomly divided into two as experimental group $(n=399)$ and control group $(n=390)$. In addition to their physical education lessons, the experimental group participated in the balance training program 3 days a week, for 8 weeks. The control group students only participated in physical education lessons. Height, body weight, body fat ratio measurements were taken before and after exercise program, flamingo balance test, $20 \mathrm{~m}$ speed test and Illinois agility test were applied. The data were evaluated in SPSS 16 program. T-test was used in dependent and independent groups in statistical analysis $(p<0.05)$. In the experimental group significant difference was found in $20 \mathrm{~m}$ speed, agility and balance values at the end of 8 weeks $(p<0.05)$. In the control group, there was no significant difference was found in these values $(\mathrm{p}>0.05)$. As a result of the study, it was determined that balance exercises have a positive effect on speed, agility and balance performance.
\end{abstract}

Keywords Physical Education Lesson, Balance, Speed, Agility

\section{Introduction}

Balance is the base of all movements. There is a constant loss and recovery of balance during movement [1]. Although balance is generally thought of as a static process, it is a highly integrated dynamic process that involves many neurological ways [2]. In order to maintain body position during an action, acceleration and deceleration, during sudden location and direction changes, there is a need for balance. Balance is required in the performance of a large number of motor tasks [3]. In order to ensure successful performance in sports activities, it is necessary to maintain high level motor performance, and to maintain and sustain static and dynamic balance [4].

It is known that the balance, which defined as the "ability to apply movements at a speed as high as possible" affects the agility [1,5] which is defined as "the ability to change direction rapidly while maintaining balance without losing speed [6], and balance is an important element for agility [7,8]. Agility is defined in two frames in general; different locomotors movements used in place of linear sprint and change of direction. The athlete's ability to accelerate, decelerate, move in the right direction, and quickly change the direction of the movement and control of the posture requires many skills [9]. Improvement of balance, including speed and explosive power, is considered to be one of the main features of agility improvement. As the result of agility training, it is aimed to develop power, balance, speed and coordination [10]. There is a significant relationship, measures static balance, between the agility and flamingo balance test. Thus, in agility, static balance is also thought to be effective. However, the agility capability requires dynamic balance rather than static balance. Dynamic balance may affect agility positively, while agility studies are also thought to improve dynamic balance [8]. Agility includes lateral movement and rapid change of direction. Therefore, it is very important to achieve a dynamic balance with agility and speed.

The ability of static and dynamic balance could be improved by the end of first pubertal age [11]. Balance begins to develop in pre-school period, peaks at the ages of 17-18 in girls, and 18-19 in boys and decreases with age [12]. Speed, which is an important motor feature that determines the efficiency in many sports branches, should be trained for this purpose as early as possible. It increases very rapidly at the ages 6 to 13. In boys and girls it increases continuously until adolescence, and there are almost no differences in performance. However, although speed success continues to increase in males, it slows down to pause in girls with adolescence [13]. As for agility performance, it increases with age, and is further improved by repetitions and physical activities. Before adolescence, there were no significant differences between boys and 
girls; after adolescence, boys' agility performance is higher than that of girls [1]. In order to develop agility properly, both general and specific exercises are used within a certain time span. It may be initiated at 5 years of age to demonstrate strategies for achieving appropriate motor skills, and should be continued in the critical development period between 9-12 years of age [14]. Planned exercises should be weighted in during this period, which will provide a structure for learning movement patterns, timing, balance and coordination [15]. For these reasons, in these critical development periods, it is crucial that students gain the characteristics of healthy balance, speed and agility with appropriate exercise programs.

In particular, the balance, which is the base of all movements, is also the body's ability to provide any desired position, and it has a positive effect on everyday life as well as these important effects for some motoric properties. Considering the fact that the immobility in today's conditions is a serious problem in this age group of children, which is a very critical period for physical development, the content and quality of physical education lessons in schools is of vital importance. For this reason, it is necessary to include exercises that have a positive effect on balance development in physical education and sports lessons, or to increase the number of these exercises in the lessons. The aim of this study is to investigate the effects of an 8 -week balance exercises applied in physical education lessons, on speed and agility in 10-12 year-old boys and girls.

\section{Materials and Methods}

\subsection{Research Group}

This study was conducted on a total of 789 volunteered primary school students; 401 boys as experimental group $(n=201)$ and control group $(n=200)$, and 388 girls as experimental group $(\mathrm{n}=198)$ and control group $(\mathrm{n}=190)$. The average age of the experimental group was $10.16 \pm 1.48$ years and the average age of the control group was $10.41 \pm 1.23$ years. Groups were selected randomly. Necessary permissions were obtained from the school administrations and parents.

The experimental group participated in the static balance training program 3 days a week for 8 weeks and also attended physical education lessons. The control group only participated in physical education lessons. Height, body weight, body fat ratio measurements were taken before and after exercise program, and flamingo balance test, $20 \mathrm{~m}$ velocity test and Illinois agility test were applied.

\subsection{Measurements}

The body weights of the students were measured by an electronic scale with a sensitivity of $0.1 \mathrm{~kg}$, and their height was measured with a $0.01 \mathrm{~cm}$ precision digital meter. Measurements were recorded in $\mathrm{kg}$ on a precision scale (Angel brand) up to 20 grams.

Measurement of Body Fat; Skinfold calliper was used for the determination of body fat ratio, measured and calculated from the triceps and calf region.

Flamingo Balance Test; Subject steps on a $50 \mathrm{~cm}$. length, $4 \mathrm{~cm}$. height and $3 \mathrm{~cm}$. width balance board with his/her dominant foot and stands in balance, while his/her other foot is bent on the knee towards the hip and held by the hand on the same side. Time starts as the subject tries to keep his/her balance on one foot for 1 minute. If they lose their balance (stops holding his/her foot, fells over board, or touches the floor somehow etc.) time is stopped. When subject climbs on the balance board and maintains his/her position described above, the time starts again. After the determined time that is 1 minute is over, each try to maintain balance (after fall) is counted and recorded.

$20 \mathrm{~m}$ Speed Test; With the start signal, subjects were asked to run $20 \mathrm{~m}$ with the maximal velocity from the start point to the finish point in the designated area. With the New Test 2000 Photocell Device placed on the start and finish lines, the time was automatically started when the subject started running and the time was stopped when the finish line was passed. The completion times of the subjects were measured in in seconds (sec), with precision in milliseconds. After 3 minutes of break and repeating the 2 nd time, the best value is recorded.

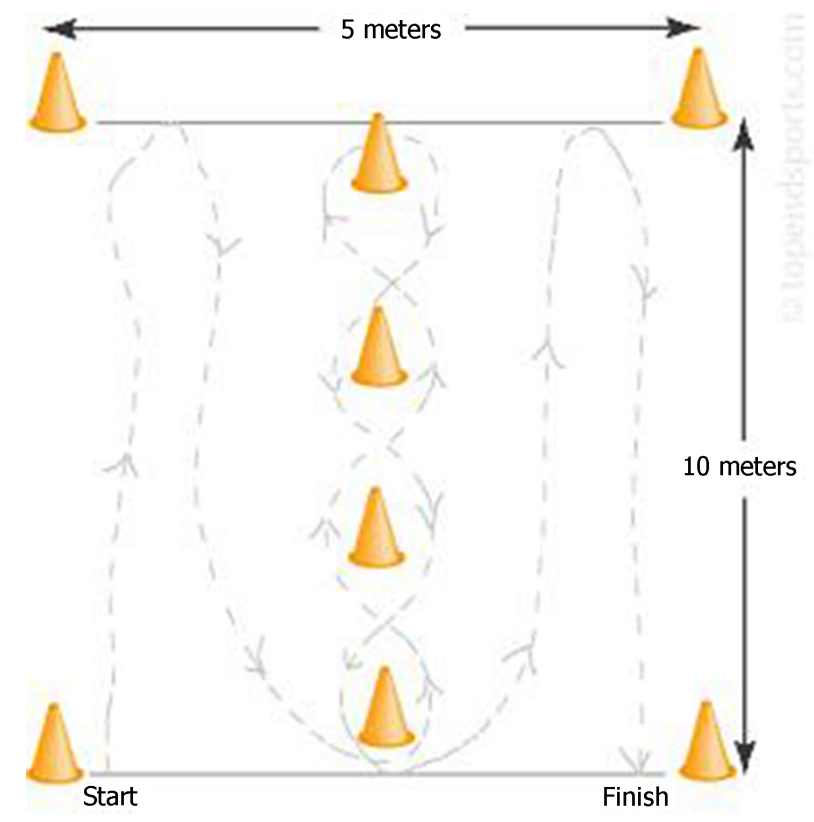

Figure 1. Illinois agility test

Illinois Agility Test; It is applied to determine the feature (ability) of agility. A test track consisting of three cones arranged on a straight line with a width of $5 \mathrm{~m}$, a length of $10 \mathrm{~m}$ and a distance of $3.3 \mathrm{~m}$ in the central section, was established. After the preparation of the test track, a two-door photocell electronic stopwatch system that is 
precision in $0.01 \mathrm{sec}$, was placed at the start and finish. Before the test, the participants were allowed to perform 3-4 trials at the low tempo following the introduction of the course and the necessary explanations, and warm-up and stretching exercises were carried out at a low tempo for 5-6 minutes. The subjects were outputted from the start line of the test track in the prone position, and with the hands in contact with the ground at the shoulder level, and the time to complete the course was recorded in seconds. They were fully rested and the test was repeated 2 times and the best value was recorded [16].

\section{Static Balance Exercise Program}

To the static balance exercise group $(n=399)$, static balance exercise program was applied for 8 weeks, 3 days a week; eyes open on the first four weeks, eyes closed on the second four weeks, each session consisted of 2 sets of 10 moves, movement duration starting from $5 \mathrm{sec}$ to $12 \mathrm{sec}$ at the end of the 8 th week. The load increase was achieved by the increase in movement time and the differentiation of muscle groups involved in the move. The full resting principle was applied between the movements and the rest period between the sets was determined as 1 minute.

Standing on one foot (right, left), tree pose (right, left), stopping on one foot (right, left), lifting the leg up to 90 degrees from the front in proper position (right, left), balancing stick with open arms (right, left), side balance (right, left), leaning forward with one foot in front of the other (right, left), forward move (right, left), side moves (right, left), backward [17].
Table 1. Static balance exercise program

\begin{tabular}{cccccc}
\hline Week & Days & Sets & Repetation & Time/sec & Recovery/sec \\
\hline 1 & 3 days & 2 & 1 & $1 \times 5 "$ & $5 "$ \\
\hline 2 & 3 days & 2 & 1 & $1 \times 5^{\prime \prime}$ & $5^{\prime \prime}$ \\
\hline 3 & 3 days & 2 & 1 & $1 \times 7.5^{\prime \prime}$ & $7.5^{\prime \prime}$ \\
\hline 4 & 3 days & 2 & 1 & $1 \times 7.5^{\prime \prime}$ & $7.5^{\prime \prime}$ \\
\hline 5 & 3 days & 2 & 1 & $1 \times 10^{\prime \prime}$ & $10^{\prime \prime}$ \\
\hline 6 & 3 days & 2 & 1 & $1 \times 10^{\prime \prime}$ & $10^{\prime \prime}$ \\
\hline 7 & 3 days & 2 & 1 & $1 \times 12^{\prime \prime}$ & $12^{\prime \prime}$ \\
\hline 8 & 3 days & 2 & 1 & $1 \times 12^{\prime \prime}$ & $12^{\prime \prime}$ \\
\hline
\end{tabular}

\subsection{Data Analysis}

The data were evaluated in SPSS 16 program. T-test was used in dependent and independent groups in statistical analysis $(\mathrm{p}<0.05)$.

\section{Results}

When the pre and post tests were compared in balance group, it was found that there was a statistically significant difference in body fat ratio, $20 \mathrm{~m}$ speed, agility and balance values in both boys and girls $(p<0.05)$. Although there were positive differences in speed, agility and balance averages in girls and boys in the control group, there was no statistically significant difference was found $(\mathrm{p}>0.05)$. There was a statistically significant difference was found in body fat ratio between in girls' control group $(\mathrm{p}<0.05)$.

Table 2. Comparison of pre-test and post-test values of the groups

\begin{tabular}{|c|c|c|c|c|c|c|c|c|}
\hline & & & & $\mathbf{n}$ & $\overline{\mathbf{x}}$ & SS & $\mathbf{t}$ & $\mathbf{p}$ \\
\hline & \multirow{12}{*}{ Boys } & \multirow{2}{*}{ Height (cm) } & pre-test & 201 & 140.17 & 10.84 & \multirow{2}{*}{1.032} & \multirow{2}{*}{0.82} \\
\hline & & & post-test & 201 & 140.61 & 10.67 & & \\
\hline & & \multirow{2}{*}{ Weight (kg) } & pre-test & 201 & 35.62 & 9.66 & \multirow{2}{*}{1.150} & \multirow{2}{*}{0.74} \\
\hline & & & post-test & 201 & 35.3 & 10.36 & & \\
\hline & & \multirow{2}{*}{ B.Fat (\%) } & pre-test & 201 & 26.67 & 6.06 & \multirow{2}{*}{2.514} & \multirow{2}{*}{$0.01 *$} \\
\hline & & & post-test & 201 & 25.16 & 5.98 & & \\
\hline & & \multirow{2}{*}{$20 \mathrm{~m}(\mathrm{sec})$} & pre-test & 201 & 4.56 & 0.42 & \multirow{2}{*}{2.388} & \multirow{2}{*}{$0.01 *$} \\
\hline & & & post-test & 201 & 4.45 & 0.50 & & \\
\hline & & Tllinac (sos) & pre-test & 201 & 20.03 & 4.57 & 474 & $001 \%$ \\
\hline & & mintois (sec) & post-test & 201 & 18.63 & 2.65 & $2.4 / 4$ & 0.01 \\
\hline \multirow{13}{*}{ Experimental Group } & & Balance & pre-test & 201 & 8.61 & 4.72 & & \\
\hline & & Balance & post-test & 201 & 7.56 & 3.55 & 2.520 & $0.01 *$ \\
\hline & \multirow{11}{*}{ Girls } & \multirow{2}{*}{ Height (cm) } & pre-test & 198 & 143.83 & 9.96 & \multirow{2}{*}{0.379} & \multirow{2}{*}{0.70} \\
\hline & & & post-test & 198 & 144.21 & 9.95 & & \\
\hline & & \multirow{2}{*}{ Weight (kg) } & pre-test & 198 & 38.66 & 10.27 & \multirow{2}{*}{0.904} & \multirow{2}{*}{0.36} \\
\hline & & & post-test & 198 & 37.76 & 9.52 & & \\
\hline & & \multirow{2}{*}{ B.Fat (\%) } & pre-test & 198 & 27.82 & 1.98 & \multirow{2}{*}{3.630} & \multirow{2}{*}{$0.000 *$} \\
\hline & & & post-test & 198 & 26.11 & 5.30 & & \\
\hline & & \multirow{2}{*}{$20 \mathrm{~m}(\mathrm{sec})$} & pre-test & 198 & 5.20 & 0.53 & \multirow{2}{*}{6.690} & \multirow{2}{*}{$0.000 *$} \\
\hline & & & post-test & 198 & 4.86 & 0.48 & & \\
\hline & & \multirow{2}{*}{ Illinois (sec) } & pre-test & 198 & 21.73 & 2.53 & \multirow{2}{*}{7.403} & \multirow{2}{*}{$0.000 *$} \\
\hline & & & post-test & 198 & 20.03 & 2.01 & & \\
\hline & & Balance & pre-test & 198 & 9.45 & 4.45 & 7.647 & 0.000* \\
\hline
\end{tabular}




\begin{tabular}{|c|c|c|c|c|c|c|c|c|}
\hline & & & post-test & 198 & 7.49 & 3.14 & & \\
\hline & & & & $\mathbf{n}$ & $\overline{\mathbf{x}}$ & SS & $t$ & $\mathbf{p}$ \\
\hline & \multirow{12}{*}{ Boys } & \multirow{2}{*}{ Height (cm) } & pre-test & 200 & 139.05 & 10.66 & \multirow{2}{*}{1.097} & \multirow{2}{*}{0.510} \\
\hline & & & post-test & 200 & 139.76 & 11.17 & & \\
\hline & & \multirow{2}{*}{ Weight (kg) } & pre-test & 200 & 36.12 & 7.61 & \multirow{2}{*}{1.782} & \multirow{2}{*}{0.10} \\
\hline & & & post-test & 200 & 37.58 & 10.16 & & \\
\hline & & \multirow{2}{*}{ B.Fat (\%) } & pre-test & 200 & 26.26 & 6.80 & \multirow{2}{*}{-1.515} & \multirow{2}{*}{0.311} \\
\hline & & & post-test & 200 & 27.91 & 6.31 & & \\
\hline & & \multirow{2}{*}{$20 \mathrm{~m}(\mathrm{sec})$} & pre-test & 200 & 4.51 & 0.57 & \multirow{2}{*}{1.260} & \multirow{2}{*}{0.50} \\
\hline & & & post-test & 200 & 4.55 & 0.64 & & \\
\hline & & Illinois (sec) & pre-test & 200 & 20.45 & 2.77 & -1844 & 0.324 \\
\hline & & & post-test & 200 & 19.57 & 3.05 & & \\
\hline \multirow{14}{*}{$\begin{array}{c}\text { Control } \\
\text { Group }\end{array}$} & & Dolon & pre-test & 200 & 8.45 & 5.18 & 1560 & 011 \\
\hline & & Darance & post-test & 200 & 7.69 & 4.48 & 1.509 & 0.11 \\
\hline & \multirow{12}{*}{ Girls } & \multirow{2}{*}{ Height (cm) } & pre-test & 190 & 143.96 & 11.28 & \multirow{2}{*}{-0.200} & \multirow{2}{*}{0.841} \\
\hline & & & post-test & 190 & 144.18 & 10.11 & & \\
\hline & & \multirow{2}{*}{ Weight (kg) } & pre-test & 190 & 39.22 & 11.28 & \multirow{2}{*}{-0.251} & \multirow{2}{*}{0.801} \\
\hline & & & post-test & 190 & 39.48 & 8.74 & & \\
\hline & & \multirow{2}{*}{ B.Fat (\%) } & pre-test & 190 & 28.21 & 6.31 & \multirow{2}{*}{-1.972} & \multirow{2}{*}{0.049} \\
\hline & & & post-test & 190 & 29.42 & 5.63 & & \\
\hline & & \multirow{2}{*}{$20 \mathrm{~m}(\mathrm{sec})$} & pre-test & 190 & 5.25 & 0.53 & \multirow{2}{*}{-0.446} & \multirow{2}{*}{0.655} \\
\hline & & & post-test & 190 & 5.18 & 0.76 & & \\
\hline & & \multirow{2}{*}{ Illinois (sec) } & pre-test & 190 & 21.86 & 2.95 & \multirow{2}{*}{-1.172} & \multirow{2}{*}{0.241} \\
\hline & & & post-test & 190 & 21.34 & 3.81 & & \\
\hline & & \multirow{2}{*}{ Balance } & pre-test & 190 & 9.75 & 3.63 & \multirow{2}{*}{1.297} & 0105 \\
\hline & & & post-test & 190 & 9.24 & 4.02 & & 0.193 \\
\hline
\end{tabular}

\section{Discussion}

In this study, which aims to observe and evaluate the effects of 8-week balance exercises in physical education lessons on 10-12 years old boys and girls; it was determined that there was a statistically significant difference between pre-test and post-test body fat ratio, 20 $\mathrm{m}$ speed, agility and balance values in both girls and boys $(p<0.05)$. In the literature, there are studies examining the effects of balance studies on the agility, speed and balance, as well as studies on the effects of agility, strength and balance on the balance.

In the studies which examine the effects of balance trainings on balance, agility and speed; Saraswat et al., (2015) [18], found that 4 weeks of balance training significantly improved agility $(p<0.05)$. In their study on the effects of 6-week dynamic balance studies on agility and vertical jump in football players, Güler and Eniseler (2017) [19], found that 6-week balance exercises significantly improve agility and explosive strength $(p=0.005)$. In the study of the effects of 6 week balance training on agility in young cricketers aged $12-16(n=66)$, Kubal and Padwal (2016) [20], performed balance studies in the experimental group for 6 weeks, besides their routine exercises, and found a significant improvement in balance and agility values $(\mathrm{p}<0.05)$. In Simek et al., (2007)'s study [21], involving physically active $75 \mathrm{men}$, the experimental group underwent the proprioceptive training program lasting ten weeks (60 minutes three times a week), the control group only continued their daily activities. They found some significant changes in the experimental group under the influence of the proprioceptive training programme in double-leg vertical jump explosive strength tests and in forward agility. Taşkın and Biçer (2015) [22], in their study which they determined the effect of an 8 -weeks proprioceptive training on agility, quickness and acceleration, 13 students studying at the school of physical education and sports, aged $23.46 \pm 2.57$ on average, participated as an experimental group. 13 students studying at the school of physical education and sports, aged $22.39 \pm 1.56$ on average, also took part in this study as a control group. When compared to the values of quickness, acceleration and agility for the experimental group, a significant difference was found out $(\mathrm{p}<0.05)$. In their study, Afyon et al., (2017) [23], divided amateur footballers $(n=40)$ into two groups as experimental and control groups. In addition to routine training, they applied 30 minutes tertian core training program to the experimental group. As the result of their study, they found that there were significant differences between players' speed and agility skills pre-test and the post-test scores of the experimental group $(\mathrm{p}=0,000)$. Hammami et al., (2016) [24], determined that 8-week studies with 4 weeks balance and 4 weeks of plyometric exercises on elite players aged 12-13, have improved sprint acceleration and balance. Chaouachi et al., (2014) [25], determined a significant improvement in $10 \mathrm{~m}$ sprint times of $12-15$ years male adolescents after 8 weeks of a combined balance and 
plyometric training program. Cerrah et. al., (2016) [26], divided football players with an average age of $14(n=16)$ into two groups as experimental and control groups. In addition to their routine training, the experimental group underwent functional balance studies for 6 weeks. As a result of their studies, they found that functional dynamic balance studies positively affect the static balance ability. Paterno et al., (2004) [27], made athletes practice balance exercises for 6 weeks with the Bosu ball, and they identified the improvement of the balance performances of the athletes. In their 6-week study with the sedentary group Aggarwal et al. (2010) [28], have found an improvement in static and dynamic balance as a result of balance and core exercises. In their study İri et al., (2018) [29], found that 8 -week balance exercises on wrestlers, reduced their body fat percentage, and increased static-dynamic balance and agility performance. The results of the present study support the literature. It can be said that balance exercises have a positive effect on speed, agility and balance development.

Some studies examining the effects of agility studies on balance; Shapie and Rohizam (2018) [30], found that agility, speed and quickness training programs in children (n-60) significantly improved their coordination and balance. Sekulic et al., (2013) [31], found that agility training in male and female athletes caused balance development in males. The results of the study reveal the relationship between balance, agility and speed. It can be said that these abilities have complementary and developing features. Hazar and Taşmektepligil (2008) [8], argued that for most of the sports activities to be successful, they depend on having the proper posture and balance in this position and to improve agility; along with the trainings which develops agility, dynamic balance exercises should be included in the trainings too. Okudur (2010) [32], found a significant relationship between balance performance and agility in 12 year old male tennis players. Draper and Lancaster (1985) [33], found a moderate severity $(\mathrm{r}=0.47)$ relationship between a 20 - mile test performance and an Illinois test, where the agility feature was tested. All of the findings show that balance studies affect agility and speed positively, and agility and speed trainings have a positive effect on balance, so balance, agility and speed characteristics are complementary features.

\section{Conclusions}

For most of the sports activities to be successful, they depend on having the proper posture and balance in this position. Especially the balance that is the base of all movements is also the ability of the body to provide any desired position, and it has positive effects for daily life as well as these important effects for some motoric features. The present study shows that balance exercises improve agility, speed and balance. The development of balance ability is very important especially in the first adolescence and after, for this reason, it is necessary to meet these needs in physical education lessons especially at these ages.

It is recommended that balance exercises should be placed in physical education lesson programs or should increase the number of balance exercises in physical education lessons.

\section{REFERENCES}

[1] L. E. Brown, V. A. Ferrigno, J. C. Santana. (Eds.). Training for speed, agility, and quickness. Champaign, IL: Human Kinetics, 2000.

[2] D. A. Padua, K. M. Guskiewicz, W. E. Prentice, R. E. Schneider, E. W. Shields. The effect of select shoulder exercises on strength, active angle reproduction, single-arm balance and functional performance. J Sport Rehab 13: 75$95,2000$.

[3] R. M. Malina, C. Bouchard. Growth, maturation, and physical activity. Human Kinetics Publishers İnc, Illinosis, 1999.

[4] N. Erkmen, S. Suveren, A. S. Göktepe, K. Yazıcıoğlu. The comparison of balance performance of the athletes who are in different branches. Spormetre, 5(3):115-122, 2007.

[5] W. B. Young, M. H. Mcdowell, B. J. Scarlett. specificity of sprint and agility training methods. The Journal of Strength \& Conditioning Research, 15: 315-319, 2001.

[6] K. A. Lemmink, M. T. Elferink-Gemser, C. Visscher. Evaluation of the reliability of two field hockey specific sprint and dribble tests in young field hockey players. British Journal of Sports Medicine, 38: 138-142, 2004.

[7] P. Chelladurai, M. S. Yuhasz. Agility performance and consistency. Canadian Journal of Applied Sport Sciences, 2: 37-41, 1977.

[8] F. Hazar, Y. Taşmektepligil. The effects of balance and flexibility on agility in prepuberte period. Spormetre Journal of physical education and Sport sciences, VI (1) 9-12, 2008.

[9] O. Sever. Comparison of static and dynamic core exercises effects on speed and agility performance in soccer players, (Unpublished doctoral dissertation). Gazi Üniversitesi Sağlik Bilimleri Enstitüsü, Beden Eğitimi ve Spor Anabilim Dali, Ankara, 2016.

[10] G. Sporiš, L. Milanović, I. Jukić, D. Omrčen, J. S. Molinuevo. The Effect of Agility Training on Athletic Power Performance, Kinesiology, 42 (1), 65-72, 2010.

[11] L. Nolan, A. Grigorenko, A. Thorstensson. Balance control: sex and age differences in 9-to 16-year-olds. Developmental Medicine \& Child Neurology, 47(07):449-454, 2005.

[12] S. Muratlı. Çocuk ve Spor Antrenman Bilimi Yaklaşımıyla. Ankara. Nobel Yayın Dağıtım. 197-219, 2003.

[13] S. Muratlı. Çocuk ve spor antrenman bilimi yaklaşımıyla, 1. Baskı, Nobel Yayın Dağıtım, Ankara, 2009. 
[14] J. Drabik. Children and sports training. how your future champions should exercise to be healthy, fit, and happy. Island Pond. Stadion Publishing Co., 1996.

[15] T. F. Besier, G. D. Lloyd, T. R. Ackland, J. L. Cochrane. Anticipatory effects on knee joint loading during running and cutting maneuvers. Medicine and Science in Sports and Exercise. 33:1176-1181, 2001.

[16] M. G. Miller, J. J. Herniman, M. D. Ricard, C. C. Cheatham, T. J. Michael. The effects of a 6 week plyometric training programme on agility. Journal of Sports Science \& Medicine, 5, 459-465, 2006.

[17] C. S. Erdoğan, F. Er, G. İpekoğlu, T. Çolakoğlu, E. Zorba, F. F. Çolakoğlu. The effects of different type balance exercises on static and dynamic balance performance in volleyball players, Journal of Sports and Performance Researches, 8 (1), 11-18, 2017. DOI: 10.17155/spd.63957.

[18] A. Saraswat, D. Malhotra, C. Sicaram. Effect of dynamic balance training on agility in male basketball players. International Journal Of Physiotherapy, 2(5), 798-803, 2015.

[19] Ö. Güler, N. Eniseler. The effects of soccer specific balance trainıng on agility and vertical jump performances in young soccer players. Journal of Physical Education and Sport Science, 11(3), 259-267, 2017.

[20] S. Kubal, D. Padwal. The effect of balance training on agility in young cricketers. International Journal of Science and Research (IJSR). 5 (10), 485-492, 2016.

[21] S. Simek, D. Milanovic, I. Jukic. The effects of proprioceptive training on jumping and agility performance. Kinesiol, 39 (2): 131-41, 2007.

[22] C. Taşkın, Y. Biçer. The effect of an eight-week proprioception training program on agility, quickness and acceleration. Turkish J Sport and Exerc, 17(2): 26-30, 2015.

[23] Y. A. Afyon, O. Mulazimoğlu, A. Boyaci. The effects of core trainings on speed and agility skills of soccer players, International Journal of Sports Science, 7(6): 239-244, 2017. doi:10.5923/j.sports. 20170706.06.

[24] R. Hammami, U. Granacher, I. Makhlouf, D. G. Behm, A. Chaouachi. Sequencing effects of balance and plyometric training on physical performance in youth soccer athletes. J
Strength Cond Res 30: 3278-3289, 2016.

[25] A. Chaouachi, A. B. Othman, R. Hammami, E. J. Drinkwater, D. G. Behm. The combination of plyometric and balance training improves sprint and shuttle run performances more often than plyometric-only training with children. J Strength Cond Res 28: 401-412, 2014.

[26] A. O. Cerrah, İ. Bayram, G. Yıldızer, O. Uğurlu, D. Şimşek, H. Ertan. Effects of functional balance training on static and dynamic balance performance of adolescent soccer players. Interl J Sports, Exerc Train Sci, 2(2): 73-81, 2016.

[27] M. V. Paterno, G. D. Myer, K. R. Ford, T. E. Hewett. Neuromuscular training improves single-limb stability in young female athletes. J Orthop Sports Phy Ther, 34(6): 305-316, 2004.

[28] A. Aggarwal, K. Zutshi, J. Munjal, S. Kumar, V. Sharma. Comparing stabilization training with balance training in recreationally active individuals. Int $\mathrm{J}$ Ther Rehabil. 17(5):244-253, 2010.

[29] R. İri, H. Engin, Z. A. Aktuğ. The effect of 8-week balance training conducted by the wrestlers who are between 12-15 years on agility and speed performance, Gaziantep University Journal of Sport Science 3(1), 81-90, 2018.

[30] M. N. M. Shapie, R. N. F. R. Rohizam. A case study: the effects of speed, agility and quickness (saq) training program on hand-eye coordination and dynamic balance among children, Journal of Physical Fitness, Medicine \& Treatment İn Sports 2(4): 1-6, 2018.

[31] D. Sekulic, M. Spasic, D. Mirkov, M. Cavar, T. Sattler. Gender-specific influences of balance, speed, and power on agility performance, The Journal of Strength \& Conditioning Research, 27(3), 802-811, 2013. Doi: 10.1519/JSC.0b013e31825c2cb0

[32] A. Okudur. The Relationship Between Balance and Agility Performance in Tennis Players Aged 12, (Unpublished masters dissertation) Antrenörlük Eğitim Anabilim Dalı, Konya, 2010.

[33] J. A. Draper, M. G. Lancaster. The 505 test: A test for agility in the horizontal plane. Australian Journal of Science and Medicine in Sport 17(1), 15-18, 1985. 